\title{
Pathways, Histories, and ScreenDance Diaries: Sarah Elgart in Conversation
}

Sarah Elgart, Choreographer \& Director, Sarah Elgart |Arrogant Elbow

Harmony Bench, The Ohio State University

HB: I was very excited to discover your Cultural Weekly column ScreenDance Diaries, which I've been following for a couple of years now. Could you talk about your background in screendance and how you navigated your own path in relation to the form?

SE: Thank you! Well, I was raised here in Los Angeles, spent a lot of time in New York, as well as in Germany at Folkwang Hochschule - Pina Bausch's school - training as a girl, and that impacted me greatly. But I came back to LA because I felt like I really needed to be home to do my own work as a choreographer. I wanted to look into using alternative space for dance performances, other than traditional theater space, I felt like this paradigm in New York was something that hadn't really been explored in Los Angeles, and I started doing that. In the mid ' 80 s, I fell into working at a women's prison, teaching maximum-security inmates, and eventually that led to me being underwritten by the now-defunct Arts in Correction aspect of the CA Department of Corrections. I wrote for and received grants from them with the California Arts Council to create choreography with inmates and started working in the prisons about 20 hours a week. A piece I created with the inmates entitled "Marrying the Hangman" won an award for choreographic innovation and ended up in the 1984 Olympic Arts Festival. During the creative process, I really wanted to capture what the inmates were doing. I got permission from the prison system to go in with a camera. How I did this, I don't know, because it's very difficult to go in and film in prisons. I wrangled a friend who was a professional cinematographer, and we shot rehearsals and a run of the performance. I was working with very, notorious maximum-security inmates, two of whom were from the Manson Family. My company had come in and seen a performance of the work by the inmates, and asked me to re-set it on them and I filmed that as well. I took to the form and the medium of film, and I was really interested in how you could manipulate movement and time, going back and forth from the prison to the company, etc. That was my first introduction to exploring the mediums of film and dance together and I really loved it.

I am the daughter of two artists, and growing up in LA I saw of experimental work. Both my parents were amazing painters, my father was an art professor at UCLA, and my mother taught art at various schools around the city. I grew up amidst a community of The International Journal of Screendance 10 (2019).

https://doi.org/10.18061/ijsd.v10i0.6831

(C) 2019 Elgart and Bench. This article is published under a Creative Commons Attribution 4.0 International License (https://creativecommons.org/licenses/by/4.0/) 
arts professionals who ranged in experience from visual arts to music to film, all of greater and lesser renown. My parents took me to see a lot of dance, theater, and foreign films - classic films by directors like Truffaut, and Fellini, Godard, and Cocteau - really amazing films with movement elements that were inexplicably like dance. The cinematic elements, and images from these films lodged themselves in my brain, and really stayed with me. They are kind of formative, archetypal images for me, and I find that I'm still constantly pursuing them, or elements of them, in my own work. The way that these films could defy gravity with movement, or go into super slow motion and so forth, and contain these magical little moments that aren't necessarily easily re-created on a stage. I think that played a lot into my interest in dance film.

And then in the mid ' 80 s, purely by accident, I fell into creating choreography for music videos, films, etc., and found that I was able to make a great living doing that, and I could support my dance company. At that time, it was not an acceptable path for an artist. I was lambasted by critics. I was creating choreography for music videos and films and showing my own work at mainstream institutions - and that just wasn't okay. Critics commented on superficialities like how me and my dancers looked, and they said things like my "growing success in commercial music video choreography paralleled the coarsening of my powers as an artist."

In the ' 80 s and '90s things started to blow up. I was accepted into Sundance twice in a row as one of four nationally selected choreographers (all concert choreographers I should add) for the Sundance Dance/Film Lab. I was working with incredible mentors there, like Michael Kidd, and Stanley Donen. And for three weeks we would explore how the intersection of dance and film worked, and how to manipulate it, and we were given all these resources - camera, DP, edit bay and editors, as well as dancers... It was paradise. I brought two of my own dancers and I also had access to an entire company to create with. That really was formative. A couple years later, I was accepted into the Directing Workshop for Women at AFI [American Film Institute], still a very prestigious program. It was a very interesting year because Karole Armitage and I were both accepted, and I don't think there's ever been two choreographers there at the same time since!

All of that really laid the groundwork for my interest in film, and simultaneously I was working regularly as a choreographer in these commercial projects, and I was fascinated by the intersection of dance and film and participating in an active inquiry about how it could be used. I really was interested in exploding the sort of traditional model that existed then of, in a music video for example, 5, 6, 7, 8, the shoulders start rolling and the dance number begins. I was working with one director in particular by the name of David Hogan and we must have done 25 or 30 projects together, and he really relied on my eye. I was working very intuitively on site, so he would bring me onto a location and say, "Sarah, what would you do here?" And he entrusted me to it. I would set up a shot, or an idea, and I was of course looking from behind the camera and creating the 
choreography, and it was very exciting for me. And then he would wait for me when he started editing, because he really liked the exchange. We had a very good working dynamic, and it was very interesting and exciting. It was a new medium. It was 1984 . I was very young and very wide-eyed and eager, and really excited by the possibilities. I was exploring what could happen and where to go with it all.

Shortly after my time at AFI's Directing Workshop for Women and the two Sundance Dance/Film Labs, I was hired by The Disney Channel to become a Music Producer for the New Mickey Mouse Club - a fact I speak little about in part because of all the commercial vs. art backlash I have received. Working there for four years until the show wrapped, I was responsible for conceiving, casting, and overseeing all aspects of three weekly music and dance numbers and two music videos a month. And yes, I worked with all those super stars as kids. I frequently co-choreographed with the show's choreographer Myles Thoroughgood, and after one year was directing music/dance numbers and music videos as well. As such I also became a DGA [Directors Guild of America] director member and learned a tremendous amount about the craft of directing.

As part of the job I would relocate for approximately half to two-thirds of the year to Orlando, coming back to LA when we were not in production, at which time I was working on my own non-commercial choreography projects within marginalized communities. One year upon returning to LA, I accepted an offer to teach an afterschool dance program in a very downtrodden, inner city school. My first day there I walked in with a stack of VHS tapes (those were the days!) - my own work and a couple from the show. Two of the kids read the labels of the tapes - they were of the show's musical numbers - and right in front of me, they IMMEDIATELY began dancing the choreography that I had worked on only weeks before. It blew me away and really hit home the power and reach of the media and I thought, if dance on film can do that, wow. After that, I took my job there even more seriously because I realized that the music and dance numbers, in their aesthetic choices of songs, production design, movement, etc. had the power to coalesce and elevate these young people to appreciate aesthetics and choices they might not otherwise be exposed to.

This is a very specific example and of course my own films and the films I write about on ScreenDance Diaries are nothing like those I did for Disney, but it relates directly to the relationship of dance and film, and what is possible at their intersection.

HB: Could you talk about why you decided to start ScreenDance Diaries as an online column, and the conversations you're trying to provoke or engage with it?

SE: I had just left Dance Camera West after about six years, and I was talking with Adam Leipzig, who's the founder of Cultural Weekly, which is the online magazine that ScreenDance Diaries is featured on. He was asking me a bunch of questions about all the dance films I had seen, and did I have a database? How many were there? Where would 
I find them? etc. And then he just pitched the idea of me writing a column. I said yes and named it ScreenDance Diaries. Dance is ephemeral, right? You know, it's only there when it's there. You can't pick it up and take it home with you. And I'm just as fascinated with live dance as I am with dance on film. But the reach of media is just undeniable... Over the past 20 plus years, since my own involvement with music videos, films, working on my own dance films, viewing so many from all over the world I really saw that film as a medium could extend the life of dance. I don't know if you ever watch music videos, but if there's a song that you are particularly fond of, and you've seen the music video and it's well done, it's hard to forget. Take for example [Childish Gambino's] recent "This Is America." It becomes difficult to listen to that song without having what I call the ghost imprint of that video in your head. Such an incredible piece of work, with a powerful and important statement, one of the best music videos I've seen in a long time. And I think that's very profound and important. Screendance becomes a very visceral way of preserving dance so that it has a life in our collective consciousness, and it promotes dialogue. I see dance on film not as a way to replace the experience of seeing dance live, which is completely different, but as a supplement, and a way of prolonging it.

HB: One of the things I really enjoy about ScreenDance Diaries is there's not a fidelity to a certain aesthetic, or a certain style of dance. When you look at work, what strikes you? Are you looking for something in particular? What do you respond to?

SE: I respond to a myriad of different things, and of course it's so subjective. It's hard to characterize what I respond to because dance is an art form - and dance film is an art form - and both are changing all the time. But now with the Web, we are, in a way, all speaking to each other as people, culturally. There are cross-pollinations happening in all art forms constantly, and I'm really excited by that. I think it's what has to happen to make the world more strongly inter-woven. We are in a time where we've got the leader of the so-called Free World focusing only on the divisions that exist between us. And the arts and dance in particular, including dance on film, have the ability to reach a large number of people and speak many languages without saying a single word. I'm interested in work that is technically well done, but I also really like stuff that is shot from the hip and not necessarily pre-planned, films that are of the moment and a form of pure expression. I'm moved by work that is original. I'm moved by work that is honest, that is unpretentious, that has great movement, that has great cutting, that has great color, that has sensitivity. Work that is human.

I did notice, particularly when I was involved with Dance Camera West, and seeing the lineup of films at other film festivals, say in New York or elsewhere, that there was a specific aesthetic, a predisposition that happened in Los Angeles that was different and singular. We were trying to promote and ignite a conversation between directors, producers, and dance film makers. There's this kind of gap between the commercial and the arts worlds, and I'm really interested in bridging that gap. I think we have tremendous amounts to learn from one another. I don't think for example that you 
necessarily have to characterize a beautifully done music video that features dance as only that, I think it can be considered a viable piece of screendance as well.

HB: I really appreciate the work that you're doing with ScreenDance Diaries, not only because I have been introduced to new films via your column, but also because you are opening screendance to a bigger audience than artists and academics. When you are curating and writing about these videos, who do you envision as your audience?

SE: I don't know, I really don't. I actually see what I'm doing as a public service. I think it's a way of educating people, about dance, and dance on film, about film, about art, about what's going on in the world in general, and the power and possibilities within the mediums. I think the possibilities are unlimited, and as a genre, it's just beginning to emerge. I think screendance will explode sometime soon in much more marketable ways. When somebody is online and encounters a piece of work that they never would've imagined existed, and it opens up doors, channels, and ideas for them - that's exciting. All those aspects play into the column, and I hope that it will open people's minds to the possibilities of what can be done in dance and film, both independently and together, and in the arts in general. There's hardly a day where I'm not viewing, and I try to really stay on top of the medium.

HB: What's next for you?

SE: I'm starting to teach annual Screen Dance Intensives, which I really enjoy. What I'm seeing now is that there are increasing possibilities for screendance, not only as a genre but in terms of marketing and using it as a promotional tool for choreographers, directors, and dancers. I've got two dance films of my own that I'm jonzing to make right now, one is more 'shot from the hip,' the other that will require some dollars. I'm getting close to launching Round 3 of Dare to Dance in Public Film Festival, an online dance film festival that I started a couple of years ago. Last year we had submissions from 11 countries all over the globe, which was super exciting. I'm being asked to curate dance film showings for venues like The Music Center, and my own live work is ongoing. I had an amazing East Coast tour this past summer premiering new work at Jacob's Pillow and Insitu Site-Specific Dance Festival in NY, and I was accepted with it into American Dance Abroad's PITCHBOOK so I'm intent on getting my stage and site work to Europe again. All that and more!

\section{Biographies}

Under the auspice Sarah Elgart | Arrogant Elbow, choreographer/director Sarah Elgart has been creating dance for stage, screen, and site-specific venues for many years. Her 
large-scale site works engage audiences by transforming and catalyzing non-traditional sites and has been presented at venues including Jacob's Pillow, INSITU Site-Specific Festival (NYC), Dance Place (D.C.), MASS MoCA, LACMA, European Culture Capitol (Belgium), and Los Angeles International Airport (LAX).

In film, Elgart has created choreography for directors including JJ Abrams, David Lynch, and Catherine Hardwicke, and her own films have received numerous awards and accolades. Elgart's critically acclaimed dance film "Ghost Story" continues to tour film festivals internationally. An alum of the Sundance Institute Dance Film Lab and AFI's Directing Women's Workshop, Elgart worked with Dance Camera West Film Festival in various capacities for nearly seven years, and currently writes a regular column on the intersections of dance and film called ScreenDance Diaries for the online magazine Cultural Weekly, where she also Executive Produces Dare to Dance in Public Film Festival. Her work in Social Justice has extended to communities including transitional homeless women and maximum-security inmates. Elgart continues to be active in "democratizing dance," challenging the notion of what is and is not a stage, and placing dance in the foreground of community and commerce.

\section{Websites: sarahelgart.com; culturalweekly.com/author/sarah}

Harmony Bench is Associate Professor in the Department of Dance at The Ohio State University. From 2014-2019, she has been co-editor of The International Journal of Screendance with Simon Ellis. She is currently at work on a collaborative research project with Kate Elswit, funded by the Arts and Humanities Research Council, which brings data visualization and computational tools of analysis to bear on dance history in the study of mid-century African American choreographer Katherine Dunham. https://dunhamsdata.org/.

Email: bench.9@osu.edu

Website: http://www.harmonybench.com 